\section{Atrioventricular canal defect in Bardet-Biedl syndrome: Clinical evidence supporting the link between atrioventricular canal defect and polydactyly syndromes with ciliary dysfunction536}

\section{To the Editor:}

Bardet-Biedl syndrome (BBS) is an autosomal recessive disorder characterized by obesity, retinitis pigmentosa, postaxial polydactyly, genito-urinary malformations, cognitive impairment, and congenital heart defect (CHD). ${ }^{1}$ Molecular basis of BBS are complex. Genetic heterogeneity is demonstrated by the identification of nine different BBS genes (BBS1-BBS9) cloned in the genome. ${ }^{2-12}$ Additionally, the genetic interaction between different loci was suspected to be involved, and triallelic inheritance has been demonstrated in several instances. ${ }^{13,14}$

The BBS phenotype overlaps with clinical manifestations of many syndromes. For example, a recessive mutation in a BBS gene has been recently identified in six fetuses clinically diagnosed as having Meckel or "Meckel-like" syndrome, demonstrating that the antenatal presentation of BBS may mimic Meckel syndrome. ${ }^{15}$ Meckel syndrome is a fetal-lethal condition presenting with renal cysts, hepatic fibrosis, postaxial polydactyly, and occipital encephalocele. ${ }^{16,17}$ The clinical diagnosis of BBS generally becomes clear during childhood, in concomitance with the development of obesity and retinal dystrophy as characteristic "markers" of the syndrome. The evolution of the phenotype with time makes the concept of clinical overlap of BBS with other condition not new. In fact, it has been previously shown that the BBS phenotype overlaps with clinical manifestations of McKusick-Kaufman syndrome, ${ }^{3,18,19}$ an autosomal recessive condition characterized by hydrometrocolpos, postaxial polydactyly and CHD. ${ }^{20,21}$ The phenotypic overlap between BBS and McKusick-Kaufman syndrome has been recognized, following the observation that infants initially diagnosed with McKusick-Kaufman syndrome, owing to the presence of polydactyly and vaginal abnormalities, develop later obesity and retinal dystrophy, resulting in the diagnosis of BBS. ${ }^{18,19}$ As occurring for Meckel syndrome, ${ }^{15}$ molecular studies demonstrated that mutations in McKusick-Kaufman syndrome gene cause a subset of BBS patients. ${ }^{2,3}$

$\mathrm{CHD}$ is occasionally found in patients with BBS, ${ }^{1}$ although studies on CHDs in BBS are effectively rare and very old, mostly published before the cloning of several BBS genes. ${ }^{1,22,23}$ The CHDs more frequently found in BBS were aortic valve anomalies, atrial septal defect, pulmonary stenosis, and dilated cardiomyopathy. ${ }^{1,22,23}$ Hypertrophy of the left ventricle was often reported as acquired cardiac defect due to renal disease and systemic hypertension. ${ }^{22}$ Nevertheless, accurate review of published reports of BBS and overlapping BBS-McKusickKaufman syndrome shows that atrioventricular canal defect (AVCD) is the prevalent CHD, 15,19,20,24,25 and dextrocardia without structural cardiac defects and abdominal situs inversus have also been described. 8,26,27 Additionally, polysplenia in the setting of heterotaxia has been reported in two sibs with BBS described by McLoughlin et al., ${ }^{28}$ although the diagnosis of BBS was questioned for these patients. ${ }^{29}$ Moreover, dextrocardia in the setting of situs inversus has been described in Meckel syndrome, ${ }^{30,31}$ and in "Meckel-like" syndrome. ${ }^{32-34}$ Additionally, we observed a patient with BBS and AVCD, which was included in our personal series of 14 patients with AVCD and postaxial polydactyly. ${ }^{24,35}$ Clinical features of this patient included macrocephaly, obesity, retinal dystrophy affecting periphery and the macular area, a post-minimus postaxial polydactyly of right hand and complete postaxial polydactyly of right foot with a well-formed toe, mild mental retardation, and CHD. Echocardiography showed visceroatrial situs solitus with levocardia, concordant atrioventricular and ventriculo-arterial connections, and a partial form of AVCD with double mitral orifice.

Thereafter, AVCD and laterality defects seem to be an important clue for the diagnosis of BBS in some cases. Actually, a possible association of cardiac malformations with syndromes with postaxial polydactyly is well-known, and published reports demonstrated a specific link with AVCD and cardiac malformations usually occurring in heterotaxia. ${ }^{35,36}$ The association between AVCD with or without common atrium is rare in the non-syndromic patients, while it is characteristic of heterotaxia syndrome with asplenia ${ }^{37}$ or polysplenia. ${ }^{38} \mathrm{CHDs}$ in heterotaxia include AVCD, common atrium, anomalous systemic and pulmonary venous drainage, persistent left superior vena cava with unroofed coronary sinus, and conotruncal defects. ${ }^{37,39}$ Among syndromes with postaxial polydactyly, the combination of AVCD and common atrium is particularly frequent in the oral-facial-digital syndromes, in short rib-polydactyly syndromes including Ellis-van Creveld syndrome, and in their related transitional phenotypes (Table 1). ${ }^{35}$ On the other hand, the association of AVCD and anomalous pulmonary venous return is specifically associated with Smith-LemliOpitz syndrome (Table 1). ${ }^{36,40}$

Recent experimental evidences regarding BBS are intriguing in regard to $\mathrm{CHD}$ and situs abnormalities. In fact, a role for several BBS proteins in regulating ciliary function has been demonstrated. ${ }^{10,11,41,42}$ It must be noticed that many clinical aspects of BBS can be explained by a ciliary defect. The finding of AVCD as partial manifestation of heterotaxia in some patients with BBS is in agreement with the involvement of BBS proteins in ciliary function, since dysfunction of the nodal cilium is known to cause left-right axis defects in vertebrates. ${ }^{43,44}$

Interestingly, it has recently been demonstrated that knockout male mouse embryos lacking the gene of oral-facial-digital syndrome type $1(O f d 1$ ) have failure of left-right axis specification with abnormal cardiac tube retaining a midline position or reversal of the heart loop. ${ }^{45}$ Ultrastructural analysis showed a lack of cilia in the embryonic node, and a specific role for the Ofd 1 protein in cilium assembly through basal body dysfunction has been demonstrated. ${ }^{45}$ As an additional observation, the MKS1 gene has recently found to be mutated in families with Meckel syndrome linked to $17 \mathrm{q}$, and comparative genomic and protemics data implicate MKS1 in ciliary functions. ${ }^{46}$ 
Table 1

Syndromes associating atrioventricular canal defect (AVCD) and postaxial polydactyly

\begin{tabular}{|c|c|c|c|}
\hline Syndrome & Type of AVCD & Extracardiac features & Gene \\
\hline Bardet Biedl syndrome & Partial AVCD & $\begin{array}{l}\text { Obesity } \\
\text { Retinitis pigmentosa } \\
\text { Postaxial polydactyly } \\
\text { Genito-urinary malformations } \\
\text { Mental retardation }\end{array}$ & BBS1-BBS9 \\
\hline Ellis-van Creveld syndrome & Partial AVCD with common atrium & $\begin{array}{l}\text { Short-limb dwarfism } \\
\text { Oral frenula } \\
\text { Oligodontia } \\
\text { Short ribs } \\
\text { Postaxial polydactyly } \\
\text { Small nails }\end{array}$ & $E V C 1-E V C 2$ \\
\hline Meckel syndrome & Partial AVCD & $\begin{array}{l}\text { Occipital encephalocele } \\
\text { Cleft lip/palate } \\
\text { Polycystic kidneys } \\
\text { Hepatic fibrosis } \\
\text { Postaxial polydactyly } \\
\text { Mental retardation }\end{array}$ & $M K S 1-M K S 3$ \\
\hline Oral-facial-digital syndromes & Partial AVCD with common atrium & $\begin{array}{l}\text { Lobulated tongue } \\
\text { Oral frenula } \\
\text { Cleft palate } \\
\text { Postaxial polydactyly }\end{array}$ & $\begin{array}{l}\text { Ofd } 1 \\
\text { Other unknown genes }\end{array}$ \\
\hline Smith-Lemli-Opitz syndrome & Partial AVCD with abnormal pulmonary venous return & $\begin{array}{l}\text { Facial anomalies } \\
\text { Microcephaly } \\
\text { Cleft palate } \\
\text { Hypospadia } \\
\text { Toe syndactyly } \\
\text { Mental retardation }\end{array}$ & DHCR7 \\
\hline
\end{tabular}

In conclusion, AVCD and laterality defects seem to be an important feature for early diagnosis of BBS. Ciliary dysfunction may have a fundamental role in determining specific cardiac phenotypes in several syndromes with postaxial polydactyly and CHD. Mutations in proteins necessary for cilium formation and functionality must be considered when investigating syndromes with postaxial polydactyly and cardiac laterality defects.

\section{Maria Cristina Digilio, MD, Bruno Dallapiccola, MD, and Bruno Marino, MD}

From the Medical Genetics, Bambino Gesù Hospital, Rome, Italy; Department of Experimental Medicine and Pathology, I University " $\mathrm{La}$ Sapienza," Rome, Italy and CSS-Mendel Institute, Rome and San Giovanni Rotondo, Italy; Pediatric Cardiology, Department of Pediatrics, I University "La Sapienza," Rome, Italy

\section{References}

1. Beales PL, Elcioglu N, Woolf AS, Parker D, et al. New criteria for improved diagnosis of Bardet-Biedl syndrome: results of a population survey. J Med Genet 1999;36:437-446.

2. Slavotinek AM, Stone EM, Mykytyn K, Heckenlively JR, et al. Mutations in MKKS cause Bardet-Biedl syndrome. Nat Genet 2000;26:15-16.

3. Katsanis N, Beales PL, Woods MO, Lewis RA, et al. Mutations in MKKS cause obesity, retinal dystrophy and renal malformations associated with Bardet-Biedl syndrome. Nat Genet 2000;26:67-70.

4. Nishimura DY, Searby CC, Carmi R, Elbedour K, et al. Positional cloning of a novel gene on chromosome 16q causing Bardet-Biedl syndrome (BBS2). Hum Molec Genet 2001;10:865-874.

5. Mykytyn K, Braun T, Carmi R, Haider NB, et al. Identification of the gene that, when mutated, causes the human obesity syndrome BBS4. Nat Genet 2001;28:188-191.

6. Mykytyn K, Nishimura DY, Searby CC, Shastri M, et al. Identification of the gene (BBS1) most commonly involved in Bardet-Biedl syndrome, a complex human obesity syndrome. Nat Genet 2002;31:435-438.

7. Badano JL, Ansley SJ, Leitch CC, Lewis RA, et al. Identification of a novel BardetBiedl syndrome protein, BBS7, that shares structural features with BBS1 and BBS2. Am J Hum Genet 2003;72:650-658.

8. Ansley SJ, Badano JL, Blacque OE, Hill J, et al. Basal body dysfunction is a likely cause of pleiotropic Bardet-Biedl syndrome. Nature 2003;425:628-633. 


\section{Digilio et al.}

9. Chiang AP, Nishimura D, Searby C, Elbedour K, et al. Comparative genomic analysis identifies an ADP-Ribosylation Factor-like gene as the cause of Bardet-Biedl syndrome (BBS3). Am J Hum Genet 2004;75:475-484.

10. Fan Y, Esmail MA, Ansley SJ, Blacque OE, et al. Mutations in a member of the Ras superfamily of small GTP-binding proteins causes Bardet-Biedl syndrome. Nat Genet 2004;36:989-993.

11. Li JB, Gerdes JM, Haycraft CJ, Fan Y, et al. Comparative genomics identifies a flagellar and basal body proteome that includes the BBS5 human disease gene. Cell 2004;117:541-552.

12. Nishimura DY, Swiderski RE, Searby CC, Berg M, et al. Comparative genomics and gene expression analysis identifies $B B S 9$, a new Bardet-Biedl syndrome gene. Am J Hum Genet 2005;77:1021-1033.

13. Katsanis N, Ansley SJ, Badano JL, Eichers EE, et al. Triallelic inheritance in BardetBiedl syndrome, a Mendelian recessive disorder. Science 2001;293:2256-2259.

14. Beales PL, Badano JL, Ross AJ, Ansley SJ, et al. Genetic interaction of BBS1 mutations with alleles at other BBS loci can result in non-Mendelian Bardet-Biedl syndrome. Am J Hum Genet 2003;72:1187-1199.

15. Karmous-Benailly H, Martinovic J, Gubler M-C, Sirot Y, et al. Antenatal presentation of Bardet-Biedl syndrome may mimic Meckel syndrome. Am J Hum Genet 2005;76:493-504.

16. Mecke S, Passarge E. Encephalocele, polycystic kidneys, and polydactyly as an autosomal recessive trait simulating certain other disorders: the Meckel syndrome. Ann Genet 1971;14:97-103.

17. Salonen R. The Meckel syndrome: clinicopathological findings in 67 patients. Am J Med Genet 1984;18:671-689.

18. David A, Bitoun P, Lacombe D, Lambert JC, et al. Hydrometrocolpos and polydactyly: a common neonatal presentation of Bardet-Biedl and McKusick-Kaufman syndromes. J Med Genet 1999;36:599-603.

19. Slavotinek AM, Biesecker LG. Phenotypic overlap of McKusick-Kaufman syndrome with Bardet-Biedl syndrome: a literature review. Am J Med Genet 2000;95:208-215.

20. McKusick VA, Bauer RL, Koop CE, Scott RB et al. Hydrometrocolpos as a simply inherited malformation. JAMA 1964;189:813-816.

21. Kaufman RL, Hartmann AF, McAllister WH. Family studies in congenital heart disease II: a syndrome of hydrometrocolpos, postaxial polydactyly and congenital heart disease. Birth Defects 1972;8:85-87.

22. Elbedour K, Zucker N, Zalzstein E, Barki Y, Carmi R et al. Cardiac abnormalities in the Bardet-Biedl syndrome: echocardiographic studies of 22 patients. Am J Med Genet 1994;52:164-169.

23. Crinò A, Tonini G, Vido L, Balsamo A, et al. La sindrome di Bardet-Biedl: studio multicentrico italiano. Riv Ital Pediatr 1994;20:530-536.

24. Digilio MC, Marino B, Toscano A, Giannotti A, et al. Atrioventricular canal defect without Down syndrome: A heterogeneous malformation. Am J Med Genet 2000;85:140-146.

25. Pyeritz RE, O’Neal Humphries J. Partial endocardial cushion defect and persistence of the left superior vena cava draining into the left atrium in a 34-year-old man with features of the Kaufman and Marfan syndromes. Johns Hopkins Med J 1980;146:28-32.

26. Sudhakar B, Rajaiah N, Gopinath TP. Dextrocardia with situs inversus in LaurenceMoon-Biedl syndrome. J Assoc Physicians India 1987;35:724-726.

27. Lorda-Sanchez I, Ayuso C, Ibanez A. Situs inversus and Hirschsprung disease: Two uncommon manifestations in Bardet-Biedl syndrome. Am J Med Genet 2000;90:80-81.
28. McLoughlin TG, Krovetz LJ, Schiebler GL. Heart disease in the Laurence-Moon Biedl-Bardet syndrome. J Pediatr 1964;65:388-399.

29. Cohen MM. Craniosynostosis: Diagnosis, evaluation, and management. New York: Raven Press 1986;497.

30. Moerman P, Verbeken E, Fryns JP, Goddeeris P, et al. Association of Meckel syndrome with M-anisosplenia in one patient. Clin Genet 1982;22:143-147.

31. Shen-Schwarz S, Dave H. Meckel syndrome with polysplenia: case report and review of the literature. Am J Med Genet 1988;31:349-355.

32. Fraser FC, Jequier S, Chen MF. Chondrodysplasia, situs inversus totalis, cleft epiglottis and larynx, hexadactyly of hands and feet, pancreatic cystic dysplasia, renal dysplasia/absence, micropenis and ambigous genitalia, imperforate anus. Am J Med Genet 1989;34:401-405.

33. Brueton LA, Dillon MJ, Winter RM. Ellis-van Creveld syndrome, Jeune syndrome, and renal-hepatic-pancreatic dysplasia: separate entities or disease spectrum? J Med Genet 1990;27:252-255.

34. Balci S, Bostanoglu S, Altinok G, Ozaltin F et al. Three sibs diagnosed prenatally with situs inversus totalis, renal and pancreatic dysplasia and cysts. Am J Med Genet 2000;90:185-187.

35. Digilio MC, Marino B, Ammirati A, Borzaga U, et al. Cardiac malformations in patients with oral-facial-skeletal syndromes: Clinical similarities with heterotaxia. Am J Med Genet 1999;84:350-356.

36. Digilio MC, Marino B, Giannotti A, Dallapiccola B, et al. Specific congenital hear defects in RSH/Smith-Lemli-Opitz syndrome: Postulated involvement of the Sonic Hedgehog pathway in syndromes with postaxial polydactyly or heterotaxia. Birth Defects Research (Part A) 2003;67:149-153.

37. Phoon CK, Neill CA. Asplenia syndrome: Insight into embryology through an analysis of cardiac and extracardiac anomalies. Am J Cardiol 1994;73:581-587.

38. Peoples WM, Moller JH, Edwards JE. Polysplenia: a review of 146 cases. Pediatr Cardiol 1983;4:129-138.

39. Webber SA, Taylor GP, Colwell K, Sandor GGS, et al. Extracardiac malformations in asplenia syndrome. Cardiol Young 1992;2:136-140.

40. Lin AE, Ardinger $\mathrm{HH}$, Ardinger $\mathrm{H}$, Cunniff C, et al. Cardiovascular malformations in Smith-Lemli-Opitz syndrome. Am J Med Genet 1997;68:270-278.

41. Ansley SJ, Badano JL, Blacque OE, Hill J, et al. Basal body dysfunction is a likely cause of pleiotropic Bardet-Biedl syndrome. Nature 2003;425:628-633.

42. Kim JC, Badano JL, Sibold S, Esmail MA, et al. The Bardet-Biedl protein BBS4 targets cargo to the pericentriolar region and is required for microtubule anchoring and cell cycle progression. Nat Genet 2004;36:462-470.

43. Supp DM, Wite DP, Potter SS, Brueckner M et al. Mutation in an axonemal dynein affects left-right asimmetry in inversus viscerum mice. Nature 1997;389:063-966.

44. Okada Y, Nonaka S, Tanaka Y, Saijoh Y, et al. Abnormal nodal flow precedes situs inversus in iv and inv mice. Mol Cell 1999;4:459-468.

45. Ferrante MI, Zullo A, Barra, Bimonte S, et al. Oral-facial-digital type I protein is required for primary cilia formation and left-right axis specification. Nat Genet 2006;38:112-117.

46. Kittala M, Tallila J, Salonen R, Kopra O, et al. MKS1, encoding a component of the flagellar apparatus basal body proteome, is mutated in Meckel syndrome. Nat Genet 2006;38:155-157. 